\title{
Survival among women with cancer of the uterine cervix: influence of marital status and social class
}

\author{
M Murphy, P Goldblatt, H Thornton-Jones, P Silcocks
}

\begin{abstract}
Study objective-The aim was to investigate whether the survival of women with cancer of the uterine cervix is associated with their marital status and social class.

Design-The study was a survey of survival up to 5 years from diagnosis of women with cancer of the cervix registered in the South Thames Cancer Registry, using Cox regression to adjust for marital status, social class, age, and stage at registration. Because of deficiencies in social class data held by the Registry (social class was assigned in only $51 \%$ of cases, as opposed to $93 \%$ for marital status), the findings were compared with survival data from the OPCS Longitudinal Study.
\end{abstract}

Setting-During the period of study (1977-81) the South Thames Cancer Registry covered a female population of about 3.5 million in the south east of England.

Patients-Data on 1728 women were analysed.

Measurements and and main resultsApparent differences in crude survival by marital status and social class were examined. These were found to be accounted for by adjustment for age and stage. The better survival of those whose social class was unknown was found to be an artefact of the way in which cancer registries assign social class, but this did not appear to bias registry based studies of social class survival seriously.

Conclusions-(1) After adjusting for age, factors affecting survival in women with cancer of the cervix, such as stage at presentation or host resistance, appear to be similarly distributed in the different marital status and social class groups; (2) for cervical cancer, the marked social class gradient and unusual marital status distribution found in cross sectional mortality data reflect the incidence of the disease, not differences in survival; (3) explanations for these patterns in incidence and mortality data are to be found in the aetiology of the disease.

Cancer of the cervix is thought to result primarily from transmission of a carcinogen, probably viral, during heterosexual intercourse. ${ }^{12}$ Reproductive factors, smoking, and long term oral contraceptive use may further increase risk, while hysterectomy and screening protect. ${ }^{3}$ Mortality statistics in
England and Wales exhibit remarkable cohort, social class, ${ }^{5}$ and marital status differences, ${ }^{67}$ antedating screening, as do incidence data elsewhere. ${ }^{89}$ For Scotland, incidence and mortality trends by marital status differ a little, but this direct comparison is not possible for England and Wales (Murphy, unpublished). Social class incidence patterns are not available for Great Britain, though the gradient in proportional registration and mortality ratios is similar for England and Wales. ${ }^{10}$ The longitudinal study carried out by the Office of Population Censuses and Surveys (OPCS Longitudinal Study) indicated broadly similar incidence and mortality patterns by marital status and social class, but is based on very small numbers. ${ }^{11}$

Table I shows standardised mortality ratios for cervical cancer by marital status and social class from the most recent Decennial Supplement. Mortality increases steadily from single to married to widows and then divorcees. For the single and married, where consistent social classification is available, mortality dramatically increases from non-manual to manual classes. The only other major cancer site (or major cause of death) with a similar pattern of mortality is lung cancer. These social statistics must be interpreted in terms of beliefs about the causes of the disease. One explanation for the unusual patterns exhibited by lung and cervical cancer might lie in the confounding of marital status with social class: lower social class women marry earlier, have higher rates of widowhood and divorce, and are less likely to remarry. ${ }^{12-14}$ However it may also be argued that these patterns reflect a simple relationship with the primary risk factors, which could be true for smoking, but there is little direct evidence that the sexual behaviour of men and women is consistent with the marital status and social class gradients. ${ }^{1015}{ }^{16}$ Alternatively marital status and social class may both affect survival, ${ }^{17-19}$ thus connecting incidence and mortality. Very few studies have addressed this last issue and accordingly we investigated whether differential survival by marital status and social class contributes to the unusual differences in mortality observed in these social groups, over and above any differences in incidence due to exposure and susceptibility.

\section{Methods}

We extracted data on women registered with cancer of the cervix by the South Thames Cancer Registry from 1968-81, when the registry covered a female population of about 3.5 million. The registry routinely abstracts the following 
Table I Standardised mortality ratios for cervical cancer, all cancers, and all causes in women by marital status and social class: England and Wales, 1979-1980, 1982-1983. Single women classified by own husband's. (All women $=100$ occupation, married by

\begin{tabular}{cccc}
\hline & $\begin{array}{c}\text { Carcinoma } \\
\text { of the } \\
\text { cervix }\end{array}$ & $\begin{array}{l}\text { All } \\
\text { cancers }\end{array}$ & $\begin{array}{l}\text { All } \\
\text { causes }\end{array}$ \\
\hline Single It & 26 & 153 & 138 \\
II & 51 & 123 & 113 \\
IIIn & 71 & 128 & 124 \\
III & 113 & 213 & 236 \\
V & 125 & 161 & 192 \\
All single & 117 & 182 & 238 \\
Married I & 70 & 170 & 121 \\
II & 36 & 89 & 70 \\
IIIn & 70 & 94 & 78 \\
III & 118 & 111 & 106 \\
V & 123 & 111 & 109 \\
All married & 90 & 115 & 125 \\
All widowed & 125 & 114 & 125 \\
All divorced & 200 & 112 & 115 \\
All women & 100 & 100 & 100 \\
\hline Source: Registrar & General's & Decennial & Supplement on \\
Occupational Mortality for Great Britain, 1979-80, \\
1982-83.
\end{tabular}

information from hospital records: sex, age, date of diagnosis, occupation (and hence social class), extent of disease at diagnosis, mode of presentation, and marital status. Linkage of patient records with the National Health Service Central Register (NHSCR) allows calculation of survival despite migration for deaths identified by NHSCR and notified to the registry. We calculated crude survival curves by marital status and social class, using the Kaplan-Meier method, ${ }^{20}$ and tested them for statistical significance using the log-rank test. ${ }^{21}$ We further

Table II Women's marital status in 1971 age 15 and over and at time of their death from various causes 1971-81, England and Wales. Number of women in each marital status category in 1971 in brackets

\begin{tabular}{llll}
\hline & \multicolumn{3}{l}{ Percentage in same marital status category at time of death as in 1971 } \\
\cline { 2 - 4 } $\begin{array}{l}\text { Marital status } \\
\text { in 1971 }\end{array}$ & All cancers & $\begin{array}{l}\text { Cancer of the } \\
\text { cervix }\end{array}$ & All causes \\
\hline Single & $95(\mathrm{n}=680)$ & $100(\mathrm{n}=10)$ & $96(\mathrm{n}=3980)$ \\
Married & $81(\mathrm{n}=3227)$ & $79(\mathrm{n}=145)$ & $72(\mathrm{n}=11677)$ \\
Widowed & $98(\mathrm{n}=1854)$ & $98(\mathrm{n}=49)$ & $99(\mathrm{n}=12879)$ \\
Divorced & $84(\mathrm{n}=89)$ & $88(\mathrm{n}=8)$ & $81(\mathrm{n}=297)$ \\
\hline
\end{tabular}

Source: Longitudinal Study 1971 Census sample

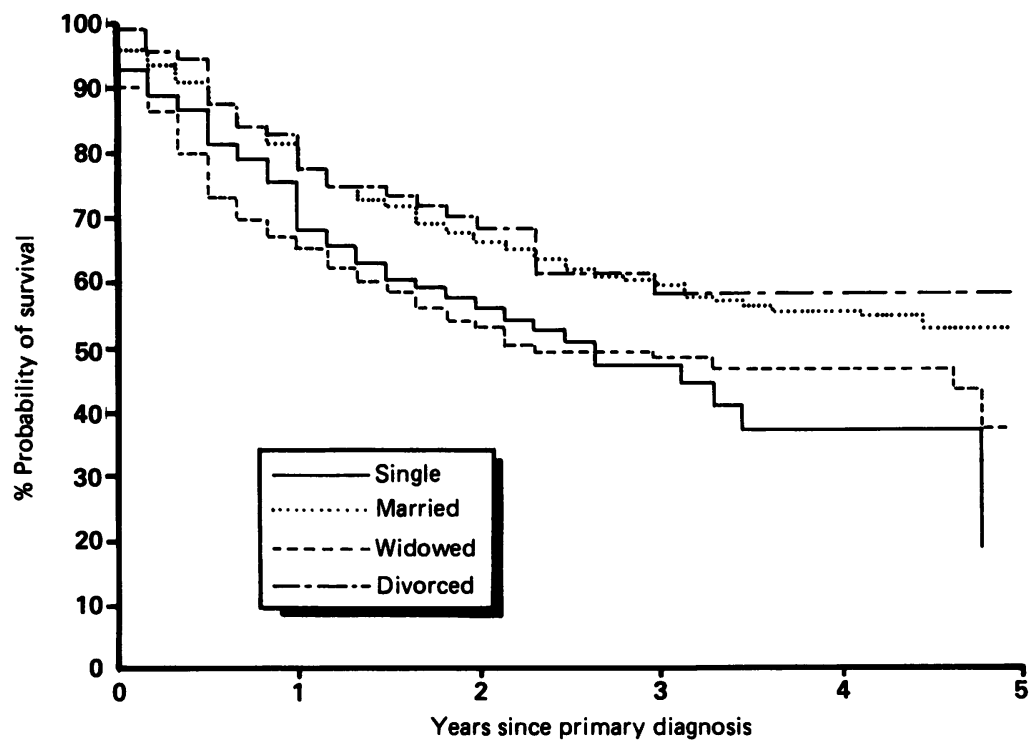

Figure 1 Survival of women with cancer of the cervix registered at South Thames Cancer Registry in the period 1977-81 by their marital status adjusted for age and stage at registration using Cox's proportional hazard's model, ${ }^{22}$ which requires considerable computing power. Because survival and the assignment of marital status and social class in $1977-81$ was very similar to that in 1968-81, we used only data from 1977-81 for Cox modelling. Using OPCS Longitudinal Study data on marital status and social class at the 1971 census for women subsequently registered with cancer of the cervix between 1971-81, we calculated transition rates between marital states to see if women developing cancer of the cervix were unusual in this respect; and we compared the quality of the Cancer Registry survival data with the Longitudinal Study data on relative survival by social class.

Indirect methods of standardisation, by age and period of survival, based on person years at risk, were used to calculate standardised fatality ratios for the OPCS Longitudinal Study data. ${ }^{11}$ Standardised fatality ratios are the percentage ratio of the number of deaths observed in a group compared to the number expected from age specific and survival period specific death rates in a comparison population. In this calculation, all those registered with the particular cancer in the OPCS Longitudinal Study were used as the comparison population. This was done separately for each year of cancer registration, allowing comparison between standardised fatality ratios for different groups in each follow up period. It also ensures that comparisons of fatality ratios for the whole follow up period are not biased by differing time trends in incidence between groups. The lower the fatality ratio the better the survival.

\section{Results}

Table II compares the marital status of women in the OPCS Longitudinal Study at the 1971 census and at their death from various causes in the period 1971-81. Transitions occur, but the pattern for cervical cancer mortality resembles that for all cancers and for all causes, suggesting that the distinctive distribution of cervical cancer by marital status is not an artefact of change between registration and death.

Figure 1 shows survival of cases registered at the South Thames Cancer Registry in the period 1977-81 by their marital status (assigned in 1607 out of 1728 cases). The single and widowed survived significantly less well than the married or divorced $\left(\chi^{2} 3 \mathrm{df}=25 \cdot 2, \mathrm{p}<0.005\right)$. However, these differences in survival were entirely explicable by differences in age, whereas variation in stage of diagnosis could not account for them. Figure 2 shows survival of the same cases by their social class (assigned in 879 out of 1728 cases). Women with an unknown social class had markedly better survival than others $\left(\chi^{2}\right.$ $3 \mathrm{df}=211.7, \mathrm{p}<0.005)$, whose experience did not differ by social class. This is because when a copy of the death certificate is available to cancer registry staff, it is often used as a source of occupational information in registering cases. This can only be done for cases known to have died. Hence information on occupation (and social class) is more likely to be missing from cancer records of those who were still alive when 
their cancer registration forms were completed. The resulting difference in survival is consequently of limited duration. In particular, in the Longitudinal Study data, it is restricted to the lag time between cancer anniversary date and dispatch of completed records to OPCS. As table III indicates, differences in survival in the Longitudinal Study between ever married women whose own or husband's social class was known and those for whom it was not known were greatest in the first two years after the women's

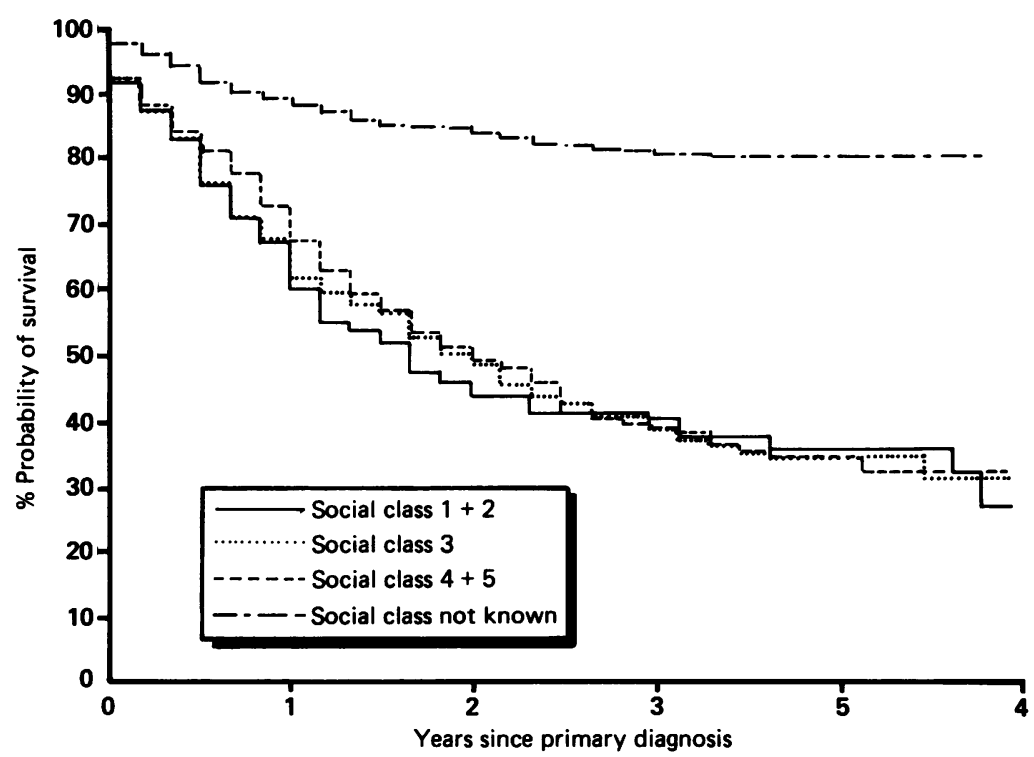

Figure 2 Survival of women with cancer of the cervix registered at South Thames Cancer Registry in the period 1977-81 by their social class cancer anniversary date. Table IV shows that this bias leads to a less serious underestimate of survival for cancer of the cervix compared to all cancers, because a smaller proportion of women die within two years. For the same reason, for cervical cancer the true social class difference is not affected markedly by whether details were provided at registration, but the same cannot be said for all cancers.

When South Thames Cancer Registry survival data by social class were examined for separate marital status groups, differences in survival were not significant for the single and divorced. Significant differences for the married and widowed were again due to the apparent excellent survival of those with unknown social class. Age adjustment did not affect these findings. There was no interaction between social class and marital status (factors which independently affected cervical cancer survival before adjusting for age but which were not important after this adjustment). OPCS Longitudinal Study data (not presented) provide no evidence to suggest that assignment biases were responsible for the absence of social class differences in cervical cancer survival within marital status categories.

\section{Discussion}

After adjustment for age, there were no significant differences in survival by marital status and social class. It is unlikely that changes in marital status or social class occur sufficiently often between cancer diagnosis and death to invalidate these findings, but caution is required in interpreting survival by social class from registry data since

Table III Standardised fatality ratios after diagnosis of cervical cancer and all cancer amongst ever married women by length of survival, recording of social class, and age at cancer registration (numbers of deaths in parentheses)

\begin{tabular}{|c|c|c|c|c|c|c|}
\hline $\begin{array}{l}\text { Cancer } \\
\text { site }\end{array}$ & $\begin{array}{l}\text { Age at } \\
\text { registration (years) }\end{array}$ & $\begin{array}{l}\text { Length of } \\
\text { survival (years) }\end{array}$ & $\begin{array}{l}\text { Husband's social } \\
\text { class stated }\end{array}$ & $\begin{array}{l}\text { Husband's social } \\
\text { class not stated, } \\
\text { own class } I-V\end{array}$ & $\begin{array}{l}\text { Neither own } \\
\text { nor husband's } \\
\text { social class stated }\end{array}$ & $\begin{array}{l}\text { All ever } \\
\text { married } \\
\text { women }\end{array}$ \\
\hline Cervix & $\begin{array}{l}15-59 \\
60+\end{array}$ & $\begin{array}{l}<2 \\
2-10 \\
<2 \\
2-10\end{array}$ & $\begin{array}{l}150(20) \\
143(5) \\
246(35) \\
188(3)\end{array}$ & $\begin{array}{c}106(20) \\
43(3) \\
133(4) \\
167(2)\end{array}$ & $\begin{array}{r}75(28) \\
123(20) \\
52(22) \\
94(25)\end{array}$ & $\begin{array}{r}98(68) \\
104(28) \\
102(61) \\
102(30)\end{array}$ \\
\hline All sites & $\begin{array}{l}15-59 \\
60+\end{array}$ & $\begin{array}{l}<2 \\
2-10 \\
<2 \\
2-10 \\
\end{array}$ & $\begin{array}{l}207(356) \\
150(82) \\
227(1382) \\
191(94)\end{array}$ & $\begin{array}{c}82(179) \\
82(91) \\
113(204) \\
82(43)\end{array}$ & $\begin{array}{l}69(326) \\
91(215) \\
61(1216) \\
94(668)\end{array}$ & $\begin{array}{c}100(861) \\
97(388) \\
101(2802) \\
99(805)\end{array}$ \\
\hline
\end{tabular}

Source: Longitudinal Study 1971 Census sample. A total of 452 deaths recorded on the same day as registration are excluded from the table. Of these, $79^{\circ}{ }_{0}$ had husband's social class stated and for a further $5 \%$ own social class was I-V. Only three of these cases related to cervical cancer

Table IV Standardised fatality ratios of married women after diagnosis of cervical cancer and all cancer, by social class at the 1971 Census and age and recording of social class at cancer registration (numbers of deaths in parentheses)

\begin{tabular}{|c|c|c|c|c|c|c|}
\hline \multirow{2}{*}{$\begin{array}{l}\text { Statement } \\
\text { of social } \\
\text { class at } \\
\text { registration }\end{array}$} & \multirow[b]{2}{*}{$\begin{array}{l}\text { Cancer } \\
\text { site }\end{array}$} & \multirow[b]{2}{*}{$\begin{array}{l}\text { Age at cancer } \\
\text { registration (years) }\end{array}$} & \multirow[b]{2}{*}{$\begin{array}{l}\text { Length of } \\
\text { survival (years) }\end{array}$} & \multicolumn{3}{|c|}{ Husband's social class at 1971 census } \\
\hline & & & & Non-manual & Manual & $\begin{array}{l}\text { Other and } \\
\text { retired }\end{array}$ \\
\hline \multirow[t]{2}{*}{ All women } & \multirow[t]{4}{*}{ Cervix } & $15-59$ & $<2$ & $108(19)$ & $83(35)$ & $128(6)$ \\
\hline & & $60+$ & $<2$ & $\begin{array}{l}58(4) \\
99(11) \\
85(5)\end{array}$ & $\begin{array}{l}115(19) \\
112(17) \\
130(10)\end{array}$ & $\begin{array}{r}154(2) \\
48(1) \\
118(2)\end{array}$ \\
\hline \multirow[t]{2}{*}{ Stated social class } & & $15-59$ & $<2-10$ & $150(3)$ & $\begin{array}{l}140(15) \\
185(5)\end{array}$ & $333(1)$ \\
\hline & & $60+$ & $<2$ & $357(5)$ & $\begin{array}{l}261(12) \\
222(2)\end{array}$ & $1000(1)$ \\
\hline \multirow[t]{2}{*}{ All women } & \multirow[t]{4}{*}{ All sites } & $15-59$ & $<2-10$ & $\begin{array}{l}86(253) \\
86(125)\end{array}$ & $\begin{array}{r}105(486) \\
99(209)\end{array}$ & $\begin{array}{l}131(44) \\
109(15)\end{array}$ \\
\hline & & $60+$ & $<2$ & $\begin{array}{l}85(464) \\
92(166)\end{array}$ & $\begin{array}{l}100(811) \\
106(262)\end{array}$ & $\begin{array}{l}97(159) \\
88(46)\end{array}$ \\
\hline \multirow[t]{2}{*}{ Stated social class } & & $15-59$ & $<2$ & $193(101)$ & $219(223)$ & $148(13)$ \\
\hline & & $60+$ & $\begin{array}{r}2-10 \\
2-10\end{array}$ & $\begin{array}{l}106(20) \\
233(231) \\
226(26)\end{array}$ & $\begin{array}{l}179(56) \\
236(430) \\
128(29)\end{array}$ & $\begin{array}{c}80(2) \\
278(78) \\
222(2)\end{array}$ \\
\hline
\end{tabular}

Source: Longitudinal Study 1971 Census sample. A total of 245 deaths recorded on the same day as registration are excluded from the table; the proportion with stated social class at registration did not vary markedly by social class at census. Only two cases related to cervical cancer. 
they are incomplete. Nevertheless, while the OPCS Longitudinal Study points to differences in survival from other cancers by social class (Leon $\mathrm{D}$, Kogevinas $\mathrm{M}$, Personal communication), it too suggests that there are no major differences for cervical cancer. This has also been suggested from a small study in Sheffield, ${ }^{23}$ though social class affected survival with cervical cancer in Sweden. ${ }^{24}$

What are the implications of our findings? Firstly, cross sectional mortality data probably reflect incidence, and the marked social class gradient and unusual marital status distribution of cancer of the cervix reflect its aetiology. Since there is little or no direct evidence of major variation in sexual behaviour in these different social groups it remains an open question what produces these differences in susceptibility. Secondly, factors which affect survival (such as histological type, method of treatment, host resistance, and delay prior to presentation/ treatment of advanced disease), may either be relatively unimportant in cervical cancer, cancel each other out, or be uniformly distributed in the different social groups. Elsewhere we found no important differences in the distribution of the principal histological types of cervical cancer by social class and marital status, although adenocarcinomas are probably more aggressive than squamous. ${ }^{25}$ Survival and fashions in the treatment of carcinoma of the cervix have been stable, largely relying on total hysterectomy and radiotherapy depending on the stage $^{26}$ and treatment compliance is unlikely to have been a problem. Variation in host resistance is difficult to quantify, though survival is probably slightly better in younger patients. ${ }^{27-29}$ Other plausible reasons for altered resistance, for example a reduced immune response accompanying stressful life events such as bereavement or divorce, ${ }^{1619}$ or nutritional differences, ${ }^{330}$ do not have a firm foundation.

Lastly, and perhaps most surprisingly, our results suggest that either stage differences are relatively unimportant in determining survival, which is unlikely, or that stage at presentation is similar by marital status and social class after age adjustment. ${ }^{23}$ While there is strong marital status and social class variation with respect to participation in the screening programme, ${ }^{31}$ mirroring the incidence and mortality of the disease, the bulk of cases identified in this way are of preinvasive disease, for which successful treatment should be offered. Although some progress to invasive disease because of false negative smears or lack of follow up, it is said that most women developing invasive cancer have never been screened. ${ }^{32}{ }^{33}$ Whether or not there are also differences by marital status and social class in the stage at presentation of symptomatic invasive disease is unknown, although there is the suggestion that this may be so..$^{34} 35$

In conclusion, therefore, we suggest that routine mortality statistics for cervical cancer closely reflect incidence in the social groups in whom monitoring is epidemiologically feasible and desirable, and that, in contrast to other cancer sites, ${ }^{36}$ studying social differences in survival from cancer of the cervix is unlikely to improve outcome among those with invasive disease.
We would like to thank Christine Hoad, of the Department of Public Health and Primary Care, Oxford, for typing the manuscript.

The work was supported by the MRC. The views expressed are not necessarily those of OPCS. Crown copyright is reserved.

1 Buckley J, Harris R, Doll R, Vessey M, Williams P. Casecontrol study of the husbands of women with dysplasia or carcinoma of the cervix uteri. Lancet 1981; ii: 1010-15.

2 Skegg D, Corwin P, Paul C, Doll R. Importance of the male factor in cancer of the cervix. Lancet 1982; ii: 581-3.

3 Brinton L, Tashima K, Lehman H, et al. Epidemiology of cervical cancer by cell type. Cancer Res 1987; 47: 1706-11.

4 Osmond C, Gardner M, Acheson E, Adelstein A. Trends in cancer mortality 1951-80, analyses by period of birth and death. London: HMSO, 1983. (Series DHI No 11, OPCS).

5 Logan WPD. Cancer mortality by occupation and social class 1851-1971. IARC Scientific publication No 36, Studies on Medical and Population Subjects No 44. OPCS. London:
HMSO, 1982.

6 Mortality according to marital status. In: Registrar General's statistical review of England and Wales for 1959, Part III. London: HMSO, 1962: 164-71.

7 Malignant neoplasms of the genital organs according to marital condition. In: Registrar General's statistical review of England and Wales for 1961, Part III. London: HMSO, 1964: 209-21

8 Ernster VL, Sacks ST, Selvin S, Petrakis NL. Cancer incidence by marital status: US Third National Cancer Survey. I Natl Cancer Inst 1979; 63: 567-85.

9 Vagero D, Persson G. Occurrence of cancer in socioeconomic groups in Sweden. Scand $\mathcal{F}$ Soc Med 1986; 14: 151-60.

10 Brown S, Vessey M, Harris R. Social class, sexual habits and cancer of the cervix. Community Med 1984; 6: 282-6.

11 Leon D. Longitudinal study: social distribution of cancer. London: HMSO, 1988. (Series LS No 3, OPCS).

12 Murphy MJ. Demographic and socioeconomic influences on recent British marital breakdown pattern. Popul Stud 1985; 39: 441-60.

13 Haskey JC. Social class and socioeconomic differentials in Haskey JC. Social class and socioeconomic differentials in
divorce in England and Wales. Popul Stud 1985; 38: 419-39. divorce in England and Wales. Popul Stud 1985; 38: 419-39.
14 Haskey JC. Social class patterns of marriage. Popul Trends 1983; 34: 12-19.

15 Mant $D$, Vessey $M$, Loudon N. Social class differences in sexual behaviour and cervical cancer. Community Med 1988; 10: $52-6$.

16 Leck I, Sibary K, Wakefield J. Incidence of cervical cancer by marital status. I Epidemiol Community Health 1978; 32 108-10.

17 Leon $D$, Wilkinson $R$. Inequalities in prognosis: socioeconomic differences in cancer and heart disease survival. OPCS Longitudinal Study: Working paper No 32, 1985.

18 Fox AJ, Goldblatt PO. Longitudinal study: Socioeconomic mortality differentials 1971-75. London: HMSO, 1982 (Series LS No 1 OPCS).

19 Jones D, Goldblatt PO, Leon D. Bereavement and cancer: some data on deaths of spouses from the longitudinal study of Office of Population Censuses and Surveys. Br Med $\mathcal{F} 1984$; 289: $461-4$.

20 Kaplan EL, Meier P. Non parametric estimation from Kaplan EL, Meier P. Non parametric estimation from
incomplete observations. $\mathcal{f}$ Am Stat Assoc 1958; 53: 457-81. incomplete observations. $\mathcal{F}$ Am Stat Assoc 1958; 53: 457-81.
21 Peto R, Pike M, Armitage P et al. Design and analysis of randomised clinical trials requiring prolonged observation of each patient. II. Analyses and examples. $\mathrm{Br} \mathcal{F}$ Cancer 1977 ; 35 : 1-39.

$22 \mathrm{Cox} D$. Regression models and life tables (with discussion). $\mathcal{F} R$ Stat Soc Series B 1972; 34: 187-220.

23 Milner P, Watts $M$. Effect of socioeconomic status on survival from cervical cancer in Sheffield. $\mathcal{f}$ Epidemiol Community Health. 1987; 41: 200-3.

24 Vagero D, Persson G. Cancer survival and social class in Sweden. F Epidemiol Community Health 1987; 41: 204-9.

25 Silcocks P, Thornton-Jones H, Murphy M. Squamous and adenocarcinoma of the uterine cervix; a comparison using routine data. Br $\mathcal{f}$ Cancer 1987; 55: 321-5.

26 Ward B, Shepherd J, Monaghan J. Occult advanced cervical cancer. Br Med f 1985; 290: 1301-2.

27 Smales E, Perry C, Ashby M, Baker J. The influence of age on prognosis in carcinoma of the cervix. Br $\mathcal{F}$ Obstet Gynaecol prognosis in carcino

28 Russell J, Blair V, Hunter R. Cervical carcinoma: prognosis in younger patients. $\mathrm{Br} M$ Med f 1987; 295: 300-3.

29 Meanwell C, Kelly K, Wilson S, et al. Young age as a prognostic factor in cervical cancer: analysis of population based data from 10,022 cases. $\mathrm{Br}$ Med F 1988; 296: 386-91. 30 Harris R, Forman D, Doll R, Vessey M, Wald N. Cancer of the cervix uteri and vitamin A. Br F Cancer 1986; 65: 653-9.

31 Eardley A, Elkind AK, Spencer B, Hobbs P, Pendleton L Haran D. Attendance for cervical cancer screening-whose problem. Soc Sci Med 1985; 20: 955-62.

32 Chamberlain J. Failures of the cervical cytology screening programme. Br Med F 1984; 289: 853-4.

33 Anonymous Cancer of the cervix; death by incompetence. Lancet 1985; ii: $363-4$.

34 Berg JW, Ross R, Latourette HB. Economic status and survival of cancer patients. Cancer 1977; 39: 467-77.

35 Mayer R, Patterson W. How is cancer treatment chosen. New Engl f Med 1988; 318: 636-8.

36 Stavraky K, Kincade J, Stewart M, Donner A. The effect of socioeconomic factors on the early prognosis of cancer. $\mathcal{F}$
Chron Dis $1987 ; 40: 237-4$. 